University of South Carolina

Scholar Commons

2014

\title{
Sustainable Thermoplastic Elastomers Derived from Renewable Cellulose, Rosin and Fatty Acids
}

\author{
Y. Liu \\ K. Yao \\ Xiaoming Chen \\ University of South Carolina - Columbia, chen25@cec.sc.edu \\ Jifu Wang \\ University of South Carolina - Columbia, wang.j@chem.sc.edu \\ Zhongkai Wang \\ zhongkai@mailbox.sc.edu
}

See next page for additional authors

Follow this and additional works at: https://scholarcommons.sc.edu/eche_facpub

Part of the Polymer Chemistry Commons

\author{
Publication Info \\ Published in Polymer Chemistry, Volume 5, Issue 9, 2014, pages 3170-3181. \\ (C) Polymer Chemistry 2014, Royal Society of Chemistry \\ Liu, Y., Yao, K., Chen, X., Wang, J., Wang, Z., Ploehn, H. J., Wang, C., Chu, F., \& Tang, C. (2014). Sustainable \\ thermoplastic elastomers derived from renewable cellulose, rosin and fatty acids. Polymer Chemistry, \\ 5(9), 3170-3181. \\ http://dx.doi.org/10.1039/C3PY01260C
}

This Article is brought to you by the Chemical Engineering, Department of at Scholar Commons. It has been accepted for inclusion in Faculty Publications by an authorized administrator of Scholar Commons. For more information, please contact digres@mailbox.sc.edu. 


\section{Author(s)}

Y. Liu, K. Yao, Xiaoming Chen, Jifu Wang, Zhongkai Wang, Harry J. Ploehn, C. Wang, F. Chu, and Chuanbing Tang 

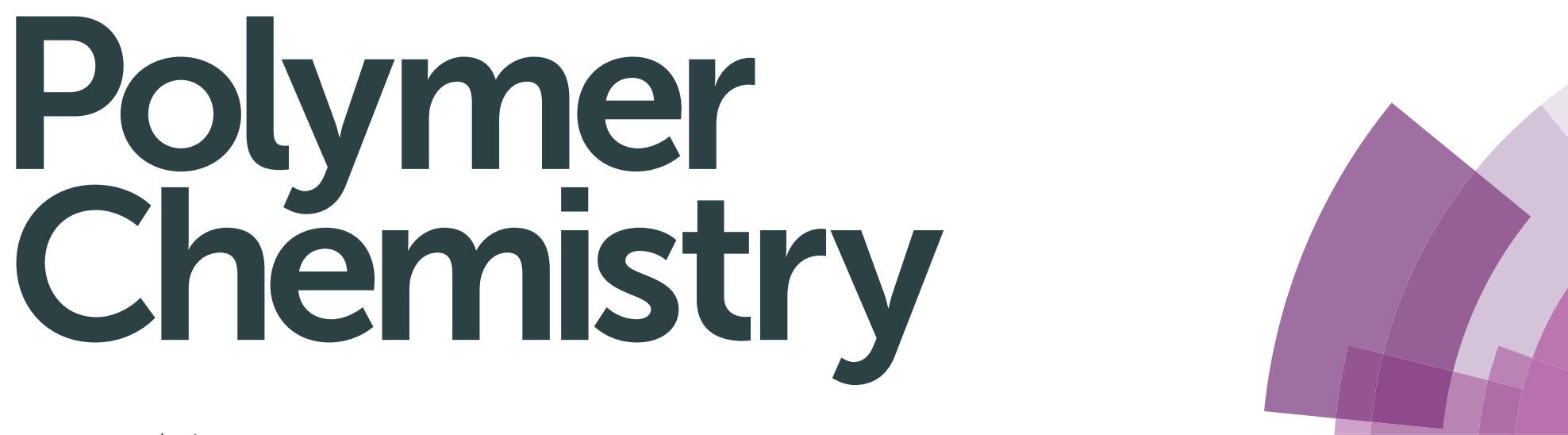

www.rsc.org/polymers

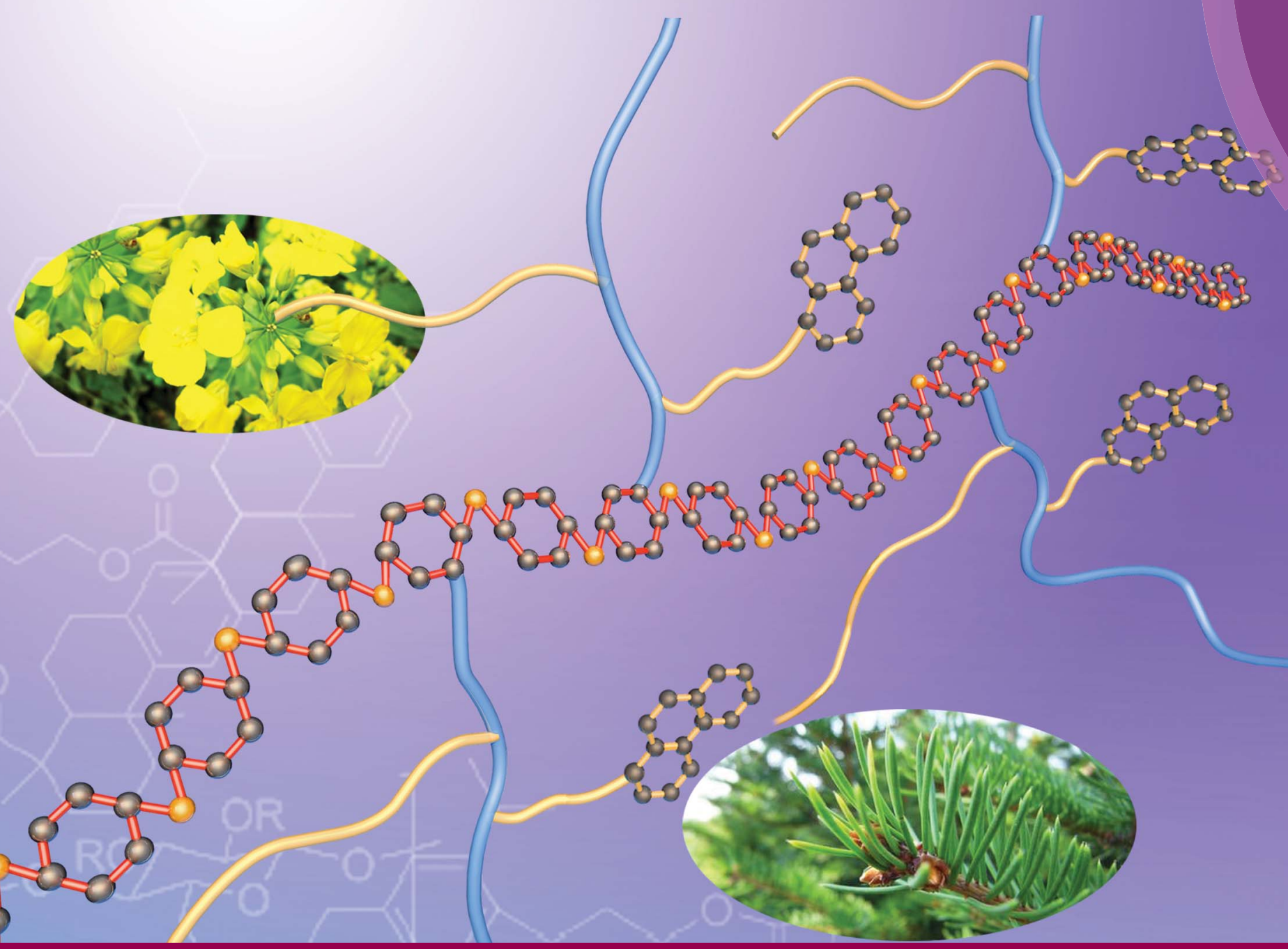

Themed issue: Sustainable polymers: replacing polymers derived from fossil fuels

ISSN 1759-9954

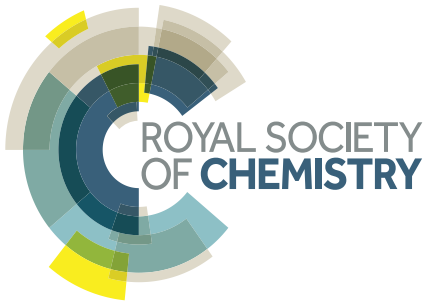


Cite this: Polym. Chem., 2014, 5, 3170

\title{
Sustainable thermoplastic elastomers derived from renewable cellulose, rosin and fatty acids
}

\author{
Yupeng Liu, $\dagger^{\mathrm{ab}}$ Kejian Yao, $\dagger^{\mathrm{b}}$ Xiaoming Chen, ${ }^{\mathrm{c}}$ Jifu Wang, ${ }^{\mathrm{a}}$ Zhongkai Wang, ${ }^{\mathrm{d}}$ \\ Harry J. Ploehn, ${ }^{c}$ Chunpeng Wang, ${ }^{a}$ Fuxiang $\mathrm{Chu}^{\star a}$ and Chuanbing Tang ${ }^{* \mathrm{~b}}$
}

Two series of graft copolymers, cellulose- $g$-poly( $n$-butyl acrylate-co-dehydroabietic ethyl methacrylate) (Cell-g-P(BA-co-DAEMA)) and cellulose-g-poly(lauryl methacrylate-co-dehydroabietic ethyl methacrylate) (Cell-g-P(LMA-CO-DAEMA)), were prepared by "grafting from" atom transfer radical polymerization (ATRP). In these novel graft copolymers, cellulose, DAEMA (derived from rosin), and LMA (derived from fatty acids) are all sourced from renewable natural resources. The "grafting from" ATRP strategy allows the preparation of high molecular weight graft copolymers consisting of a cellulose main chain with acrylate copolymer side chains. By manipulating the monomer ratios in the P(BA-CO-DAEMA) and $\mathrm{P}(\mathrm{LMA}-\mathrm{CO}-\mathrm{DAEMA})$ side chains, graft copolymers with varying glass transition temperatures $(-50-60$ ${ }^{\circ} \mathrm{C}$ ) were obtained. Tensile stress-strain and creep compliance testing were employed to characterize mechanical properties. These novel graft copolymers did not exhibit linear elastic properties above about $1 \%$ strain, but they did manifest remarkable elasticity at strains of $500 \%$ or more. These results suggest that these cellulose-based, acrylate side-chain polymers are potential candidates for service as thermoplastic elastomers materials in applications requiring high elasticity without rupture at high strains.

Received 10th September 2013 Accepted 20th December 2013

DOI: $10.1039 / c 3 p y 01260 c$

www.rsc.org/polymers in many fields, including automotive parts, sporting goods, and medical devices. First generation TPEs consist of ABA triblock copolymers in which hard minority domains of block A are microphase-separated within a soft matrix of block B. Triblock copolymers, including polystyrene- $b$-polybutadiene- $b$-polystyrene (SBS) and polystyrene- $b$-polyisoprene- $b$-polystyrene (SIS) synthesized by anionic polymerization, have been used as commercial TPE materials for several decades. ${ }^{16-18}$ Also (meth)acrylic based ABA triblock copolymers such as poly(methyl methacrylate)- $b$-poly( $n$-butyl acrylate)- $b$-poly(methyl methacrylate) (PMMA- $b$-PBA- $b$-PMMA) prepared by atom transfer radical polymerization (ATRP) have been reported as TPE materials. ${ }^{\mathbf{1 9 - 2 4}}$ All of these TPE materials based on ABA triblock copolymers and some star block copolymers ${ }^{\mathbf{1 9 , 2 5}}$ are derived from fossil fuel sources.

Recently, triblock copolymer-based TPEs sourced from renewable natural resources have drawn attention. Matyjaszewski and co-workers prepared poly $(\alpha$-methylene- $\gamma$ butyrolactone)- $b$-poly $(n$-butyl acrylate)- $b$-poly $(\alpha$-methylene- $\gamma$ butyrolactone) (PMBL- $b$-PBA- $b$-PMBL) triblock copolymers as TPEs by ATRP, in which MBL (tulipalin A) is a renewable natural resource isolated from tulips. ${ }^{26-28}$ The Hillmyer group reported a series of triblock copolymers with biobased poly(lactic acid) as end blocks. ${ }^{29-32}$ Although various renewable resources have been employed to prepare TPEs, these partially renewable ABA triblock copolymers usually require multi-step polymerizations and have inferior mechanical properties compared with their petroleumbased counterparts (SBS/SIS). 
Going beyond the first-generation ABA triblock TPEs, nextgeneration TPE materials based on graft copolymers have been developed in the past several years. These graft copolymers consist of either soft backbone and hard side chains, or rigid backbone and rubbery side chains, which can be prepared by various grafting chemistry strategies. ${ }^{25,33-36}$ For instance, polyisoprene- $g$-polystyrene (PI- $g$-PS) has been synthesized via anionic polymerization as graft copolymer-based TPE. ${ }^{34,35}$ The Kramer and Bazan groups developed a graft copolymer by grafting soft $n$-butyl acrylate from rigid polyethylene copolymer backbone through ATRP. ${ }^{37}$ Recently, we used activator-regenerated electron transfer (ARGET) ATRP $^{38}$ to prepare a series of cellulose-based graft copolymers, cellulose- $g$-poly( $n$-butyl acrylate-co-methyl methacrylate), as new candidate TPE materials. To the best of our knowledge, all graft copolymer TPEs prepared to date have been derived from petroleum-based resources. Graft copolymer TPEs sourced from renewable resources have not been reported in the literature.

In this work, we report the synthesis and characterization of cellulose-based graft copolymers derived from natural rosin, fatty acids, or both (Scheme 1), including cellulose- $g$-poly(n-butyl acrylate-co-dehydroabietic ethyl methacrylate) (Cell- $g$ $\mathrm{P}(\mathrm{BA}-\mathrm{co}$-DAEMA)) and cellulose- $g$-poly(lauryl methacrylate-codehydroabietic ethyl methacrylate) (Cell- $g$-P(LMA-co-DAEMA)). Cellulose is an abundant renewable biopolymer. ${ }^{39-41}$ DAEMA is a methacrylate-based monomer containing renewable resin acid from rosin, ${ }^{42-50}$ and LMA is derived from a renewable fatty acid. In our related previous work, we reported the polymerization of DAEMA monomer by ATRP to produce homopolymers and block copolymers with controlled molecular weight and low polydispersity index. ${ }^{51-53}$ Now, in this work, DAEMA and BA monomers are copolymerized from a cellulose backbone by "grafting from" ATRP. Due to the different glass transition temperatures of PDAEMA (high $T_{\mathrm{g}}$ ) and PBA (low $T_{\mathrm{g}}$ ), graft copolymers with controlled $T_{\mathrm{g}}$ are achieved by manipulating the monomer ratios in $\mathrm{P}$ (BA-co-DAEMA) side chains. In parallel, we replace the $\mathrm{BA}$ with another soft monomer, $\mathrm{LMA},{ }^{54,55}$ aiming to obtain a graft copolymer Cell-g-P(LMA-co-DAEMA) based completely on renewable feedstocks. The thermal and mechanical properties of both Cell- $g$-P(BA-co-DAEMA) and Cell-
$g$-P(LMA-co-DAEMA) were characterized to evaluate their potential utility as TPEs.

\section{Results and discussion}

\section{Synthesis of graft copolymers Cell-g-P(BA-co-DAEMA) and Cell-g-P(LMA-co-DAEMA)}

As shown in Scheme 2, cellulose-based graft copolymers were prepared by "grafting from" ATRP using cellulose 2-bromoisobutyrylate (Cell-BiB) as macroinitiator, copper(I) bromide (CuBr) as catalyst and $N, N, N^{\prime}, N^{\prime}, N^{\prime \prime}$-pentamethyldiethylenetriamine (PMDETA) as ligand. Cell-BiB macroinitiator was synthesized according to previous reports (Br content: $\left.3.17 \mathrm{mmol} \mathrm{g}^{-1}\right) .^{38,56}$ Utilizing the Cell-BiB macroinitiator, DAEMA and BA were copolymerized in toluene with the molar ratio of $[\mathrm{M}]:$ [Cell$\mathrm{BiB}]:[\mathrm{CuBr}]:[\mathrm{PMDETA}]=1000: 1: 1: 1$. By manipulating the feed ratio of DAEMA and BA, a series of Cell- $g$-P(BA-co-DAEMA) graft copolymers with various compositions were prepared (Table 1).

In the ${ }^{1} \mathrm{H}$ NMR spectra of Cell- $g$-P(BA-co-DAEMA) graft copolymers (Fig. 1), the peaks between 5.5 and 6.5 ppm, corresponding to the vinyl protons in both DAEMA and BA monomers, disappeared completely, indicating the success of ATRP of DAEMA and BA from the cellulose macroinitiator. The peaks at 6.8-7.2 ppm were assigned to the aromatic protons in DAEMA. The peaks in the range of 3.7 to $4.3 \mathrm{ppm}$ corresponded to the methylene protons next to the ester groups in both DAEMA and BA units. The molar ratio of DAEMA/BA can be calculated using

$$
\frac{\operatorname{mole}(\text { DAEMA })}{\operatorname{mole}(\mathrm{BA})}=\frac{\frac{I_{\mathrm{a}}}{3}}{\frac{I_{\mathrm{bc}}-\frac{4}{3} I_{\mathrm{a}}}{2}}
$$

where $I_{\mathrm{a}}$ is the integration area of aromatic protons in DAEMA moiety, and $I_{\mathrm{bc}}$ is the integration area of methylene protons next to the ester groups from both DAEMA and BA units. As summarized in Table 1, the molar ratios of DAEMA/BA in Cell- $g$ $\mathrm{P}(\mathrm{BA}-$ - 0 -DAEMA $)$ are quite close to the molar feed ratios of the
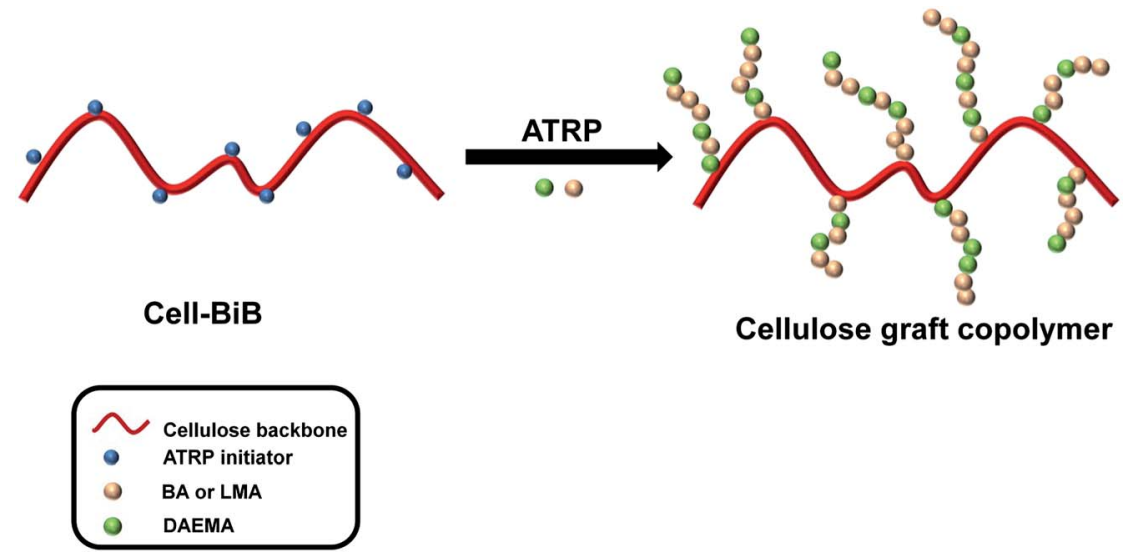

Scheme 1 Cellulose based graft copolymers by "grafting from" ATRP. 


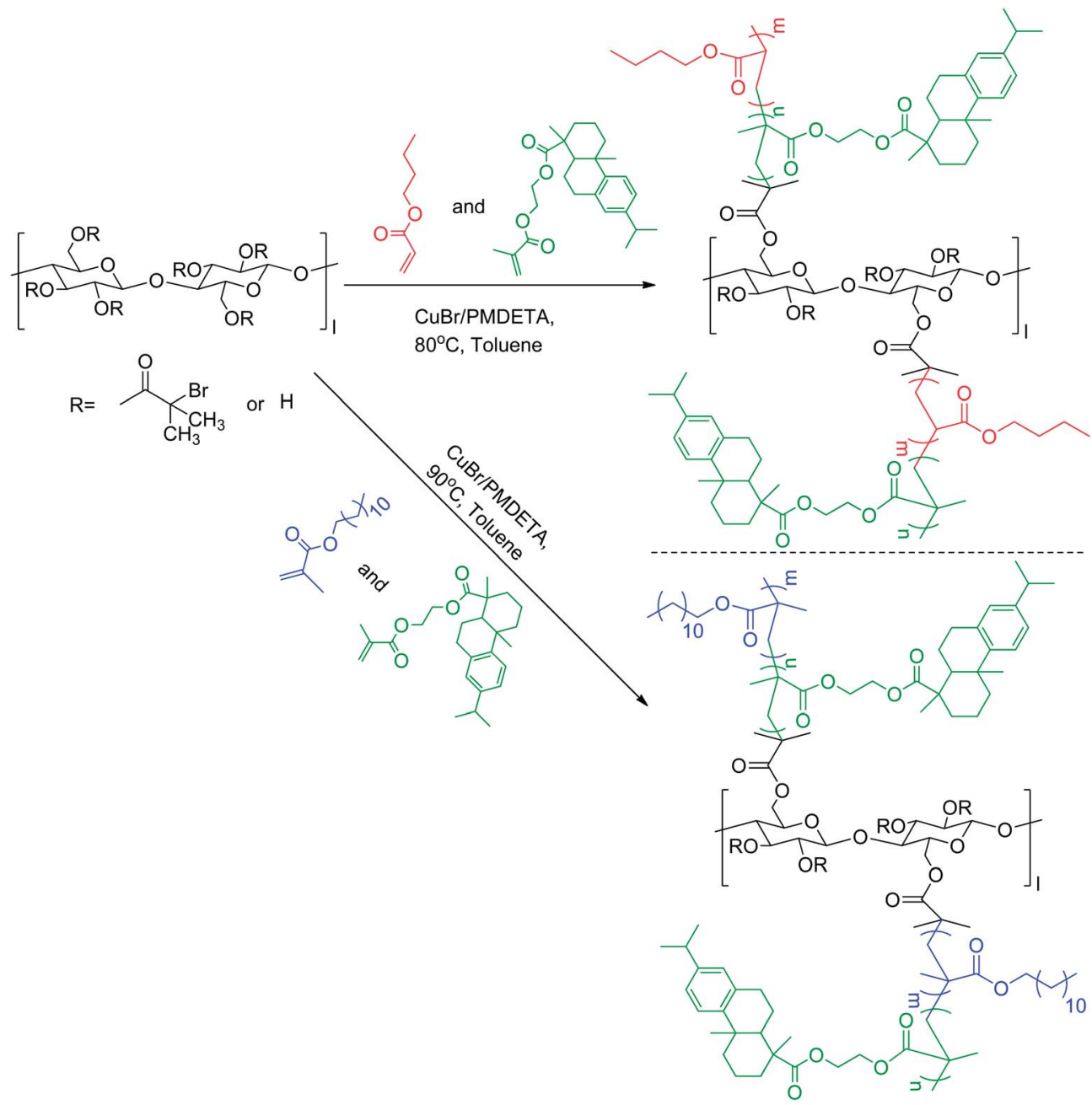

Scheme 2 Synthesis of renewable graft copolymers Cell-g-P(BA-co-DAEMA) and Cell-g-P(LMA-co-DAEMA) by "grafting from" ATRP.

two monomers, indicating the similar reactivity of DAEMA and BA monomers during the polymerization.

The successful synthesis of Cell- $g$-P(BA-co-DAEMA) by ATRP motivated us to prepare a novel, fully renewable graft copolymer, Cell- $g$-P(LMA-co-DAEMA), replacing the petroleum-based butyl acrylate (BA) with lauryl methacrylate (LMA) derived from natural fatty acids. Similar to the synthesis of Cell- $g$-P(BA-coDAEMA), LMA and DAEMA were copolymerized using Cell-BiB as macroinitiator and CuBr/PMDETA as catalyst/ligand system.
Cell- $g$-P(LMA-co-DAEMA) with different LMA/DAEMA compositions were prepared by controlling the feed ratio of LMA and DAEMA monomers. Table 2 summarizes the characteristics of Cell- $g$-P(LMA-co-DAEMA).

Fig. 2 shows a representative ${ }^{1} \mathrm{H}$ NMR spectrum of Cell- $g$ $\mathrm{P}($ LMA-co-DAEMA). The disappearance of vinyl proton peaks between 5.5 and 6.5 ppm suggested the successful ATRP of LMA and DAEMA from the cellulose backbone. Comparing the spectrum in Fig. 2 with the ${ }^{1} \mathrm{H}$ NMR spectrum of Cell-g-P(BA-co-

Table 1 Characteristics of Cell-g-P(BA-co-DAEMA) graft copolymers

\begin{tabular}{|c|c|c|c|c|c|c|}
\hline Sample name ${ }^{a}$ & {$[\mathrm{M}] /[\mathrm{I}]$} & PBA content ${ }^{b}$ (mol\%) & PBA content (wt\%) & $M_{\mathrm{n}}^{c}\left(\mathrm{~g} \mathrm{~mol}^{-1}\right)$ & PDI & $T_{\mathrm{g}}{ }^{d}\left({ }^{\circ} \mathrm{C}\right)$ \\
\hline BA90DAEMA10 & 1000 & 88.1 & 69.7 & 54800 & 2.40 & -15.6 \\
\hline BA80DAEMA20 & 1000 & 85.1 & 64.0 & 40700 & 3.95 & 0.6 \\
\hline BA75DAEMA25 & 1000 & 77.7 & 52.0 & 49300 & 1.90 & 14.1 \\
\hline BA70DAEMA30 & 1000 & 68.9 & 40.8 & 31700 & 3.95 & 16.4 \\
\hline BA60DAEMA40 & 1000 & 66.9 & 38.6 & 28000 & 3.17 & 41.2 \\
\hline BA50DAEMA50 & 1000 & 54.9 & 27.4 & 27000 & 3.92 & 59.2 \\
\hline
\end{tabular}

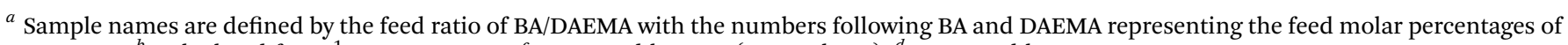
monomers. ${ }^{b}$ Calculated from ${ }^{1} \mathrm{H}$ NMR spectra. ${ }^{c}$ Measured by GPC (THF solvent). ${ }^{d}$ Measured by DSC. 


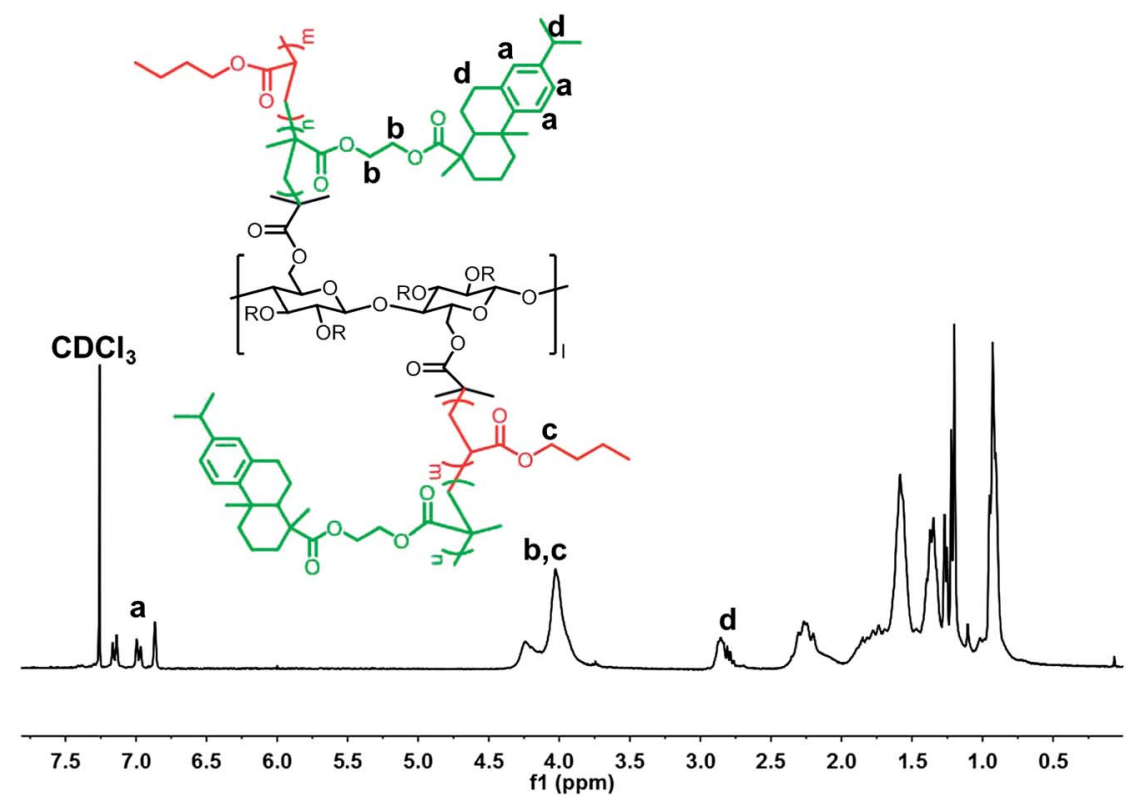

Fig. 1 Typical ${ }^{1} \mathrm{H}$ NMR spectrum of Cell-g-P(BA-co-DAEMA), sample BA70DAEMA30.

Table 2 Results of graft copolymers Cell-g-P(LMA-CO-DAEMA)

\begin{tabular}{|c|c|c|c|c|c|c|}
\hline Sample name ${ }^{a}$ & {$[\mathrm{M}] /[\mathrm{I}]$} & PLMA content ${ }^{b}(\mathrm{~mol} \%)$ & PLMA content (wt\%) & $M_{\mathrm{n}}^{c}\left(\mathrm{~g} \mathrm{~mol}^{-1}\right)$ & PDI & $T_{\mathrm{g}}{ }^{d}\left({ }^{\circ} \mathrm{C}\right)$ \\
\hline LMA90DAEMA10 & 1000 & 91.2 & 86.5 & 242600 & 2.67 & -48.0 \\
\hline LMA80DAEMA20 & 1000 & 81.1 & 72.6 & 101100 & 4.35 & -27.3 \\
\hline LMA65DAEMA35 & 1000 & 68.1 & 56.8 & 129900 & 3.71 & 8.6 \\
\hline LMA60DAEMA40 & 1000 & 61.5 & 49.6 & 83300 & 3.52 & 10.6 \\
\hline LMA50DAEMA50 & 1000 & 56.9 & 44.9 & 200100 & 4.62 & 27.5 \\
\hline
\end{tabular}

${ }^{a}$ Sample names are defined by the feed ratio of LMA/DAEMA, the numbers behind LMA and DAEMA represent the feed molar percentages of monomers. ${ }^{b}$ Calculated from ${ }^{1} \mathrm{H}$ NMR spectra. ${ }^{c}$ Measured by GPC (THF solvent). ${ }^{d}$ Measured by DSC.

DAEMA) in Fig. 1, the characteristic proton peaks (aromatic protons a and methylene protons b, c) have almost same chemical shift, indicating the similar chemical structures of two graft copolymers. Due to the similar chemical structures of LMA and BA (both have methylene protons next to ester groups), the LMA molar content was also determined by eqn (1). Once again, the molar content of LMA and DAEMA determined from ${ }^{1} \mathrm{H}$ NMR correlates closely with the monomers' molar feed ratio.

The molecular weights of Cell- $g$-P(BA-co-DAEMA) and Cell- $g$ P(LMA-co-DAEMA) graft copolymers were measured by GPC using THF as eluent solvent. As shown in Fig. 3, the GPC traces of the two graft copolymers are shifted to higher molecular weight compared to the Cell-BiB macroinitiator (black curve, $M_{\mathrm{n}}$ $=15500 \mathrm{~g} \mathrm{~mol}^{-1}$, PDI = 1.86). The molecular weight $\left(M_{\mathrm{n}}\right)$ and polydispersity index (PDI) values of the two graft copolymers are listed in Tables 1 and 2, respectively. Considering the high PDI value of cellulose macroinitiator (PDI $=1.86)$, the high PDI values (2-4) of the graft copolymers are not surprising. Also, some of the GPC traces for the Cell- $g$-P(LMA-co-DAEMA) graft copolymers show bimodal shapes, indicating that ATRP of LMA/
DAEMA was less controlled compared with that of BA/DAMEA system, in which all the GPC traces showed monomodal curves.

We acknowledge the use of some organic solvents at the current stage of our project, although our long-term goal is to have a low $E$-factor using a more eco-friendly process (e.g. aqueous emulsion polymerization). However, one of major purposes of this paper is to illustrate that renewable monomers (LMA and DAEMA) can be polymerized from a cellulose backbone. On the other hand, our polymers are greener than most commercial polymers (e.g. SBS and SIS based polymers).

\section{Thermal properties}

Glass transition temperatures $\left(T_{\mathrm{g}}\right)$ of all graft copolymers were characterized using differential scanning calorimetry (DSC). As shown in Fig. 4, all DSC traces of cellulose-based graft copolymers yielded a single $T_{\mathrm{g}}$ value. The $T_{\mathrm{g}}$ values for both Cell- $g$ $\mathrm{P}$ (BA-co-DAEMA) and Cell- $g$-P(LMA-co-DAEMA) increased with the feed molar percentage of DAEMA. The $T_{\mathrm{g}}$ values for Cell- $g$ $\mathrm{P}$ (BA-co-DAEMA) increase from $-15{ }^{\circ} \mathrm{C}$ to $60{ }^{\circ} \mathrm{C}$ as DAEMA feed percentage increases from $10 \%$ to $50 \%$ (Fig. $4(\mathrm{~A})$ ). The $T_{\mathrm{g}}$ values of Cell- $g$-P(LMA-co-DAEMA) increase from $-48{ }^{\circ} \mathrm{C}$ to $27{ }^{\circ} \mathrm{C}$ as 


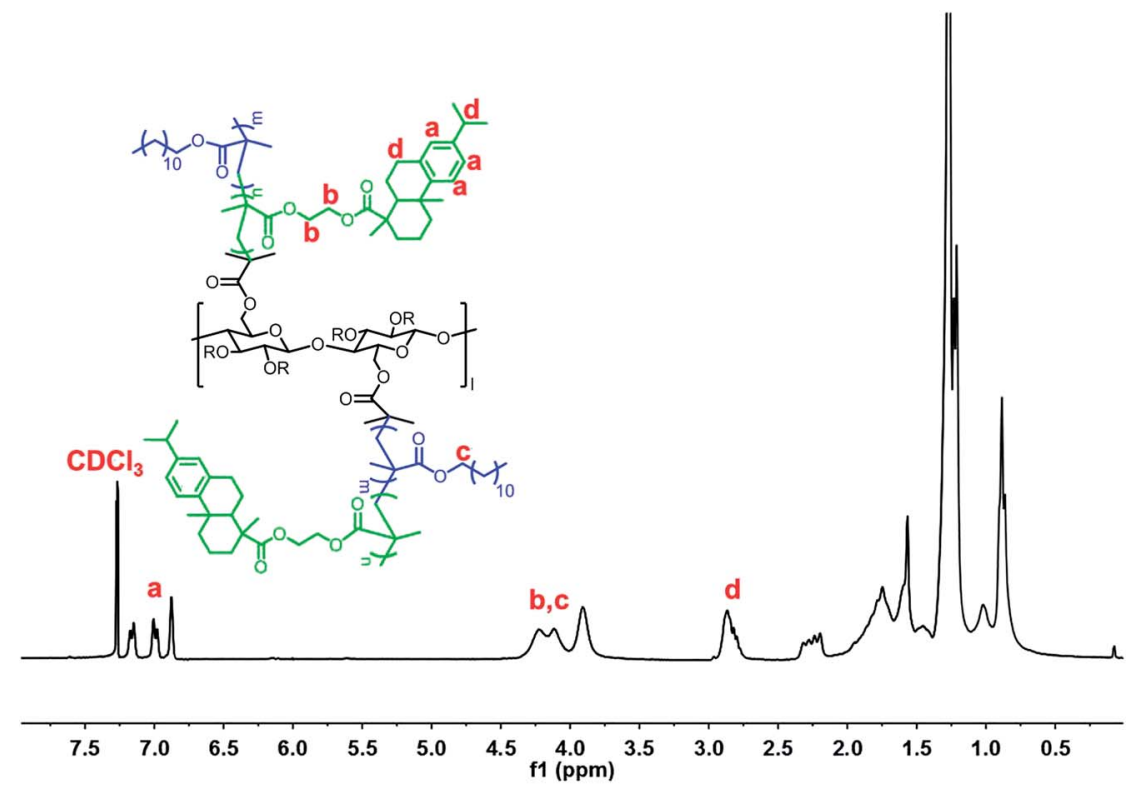

Fig. 2 Typical ${ }^{1} \mathrm{H}$ NMR spectrum of Cell-g-P(LMA-co-DAEMA), sample LMA60DAEMA40.
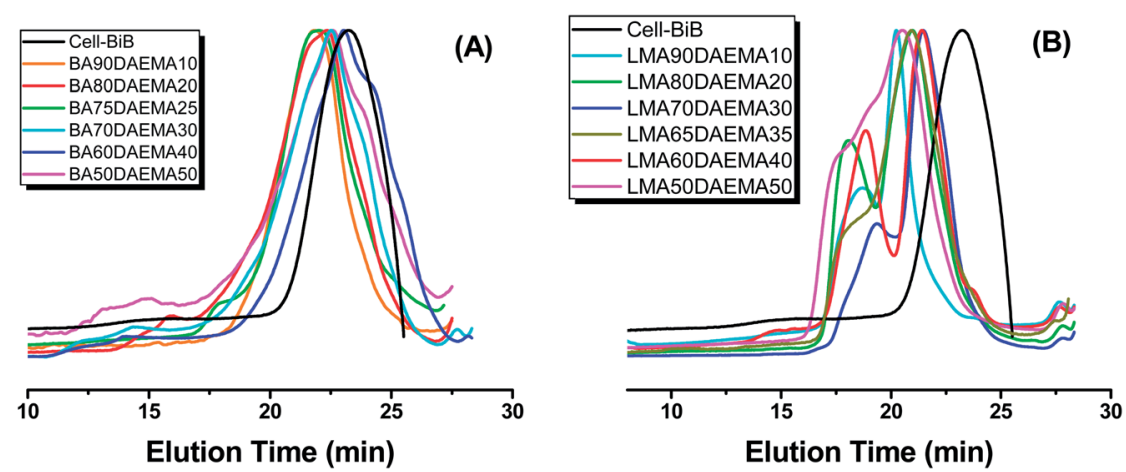

Fig. 3 GPC traces of (A) Cell-g-P(BA-co-DAEMA) and (B) Cell-g-P(LMA-co-DAEMA) graft copolymers.

DAEMA feed percentage increases from $10 \%$ to $50 \%$ (Fig. 4(B)). The DAMEA has a bulky hydrophenanthrene ring, and DAMEA homopolymer has a high $T_{\mathrm{g}}\left(\sim 90{ }^{\circ} \mathrm{C}\right) . .^{51}$ Therefore, we expect that the increase of DAEMA content in the graft copolymers leads to lower chain mobility and thus higher $T_{\mathrm{g}}$ values. Comparing the two kinds of graft copolymers with similar DAMEA molar content, Cell- $g$-P(LMA-co-DAEMA) copolymers always have lower $T_{\mathrm{g}}$ values than the corresponding Cell- $g$-P(BAco-DAEMA) copolymers, probably due to the longer flexible alkyl chains of LMA compared to the more compact BA monomers.

The thermal stability of Cell- $g$-P(BA-co-DAEMA) and Cell- $g$ $\mathrm{P}$ (LMA-co-DAEMA) graft copolymers was studied by thermal gravimetric analysis (TGA). The cellulose macroinitiator exhibited a weight loss with onset temperature at $\sim 250{ }^{\circ} \mathrm{C}$. After incorporating $\mathrm{P}(\mathrm{BA}-c o$-DAEMA) side chains, all of the TGA curves for Cell- $g$-P(BA-co-DAEMA) showed increased onset decomposition temperature of $\sim 370{ }^{\circ} \mathrm{C}$, independent of the DAEMA molar content. For Cell-g-P(LMA-co-DAEMA) graft copolymers, the onset decomposition temperature is all greater than that of Cell-BiB and generally increases (from $\sim 250$ to $\sim 325{ }^{\circ} \mathrm{C}$ ) with DAEMA molar content. The increasing thermal stability of Cell-g-P(LMA-co-DAEMA) with increasing DAEMA content can be explained by the higher thermal stability of DAEMA's hydrophenanthrene moiety, which compensates for the lower thermal stability of LMA. However, the graft copolymers containing LMA are less thermally stable than the corresponding copolymers containing BA (Fig. 5).

\section{Mechanical properties}

Mechanical properties of Cell- $g$-P(BA-co-DAEMA) and Cell- $g$ $\mathrm{P}(\mathrm{LMA}$-co-DAEMA) graft copolymers were characterized by tensile stress-strain and creep compliance testing. Considering the Cell- $g$-P(BA-co-DAEMA) graft copolymers, sample BA90DAEMA10 forms tacky films at room temperature that are more liquid-like than elastic due to the high BA content and low $T_{\mathrm{g}}$, making them unsuitable for tensile testing. Samples BA60DAEMA40 and BA50DAEMA50 are too brittle to form films for tensile testing: the relatively high $T_{\mathrm{g}}$ of graft copolymers with 

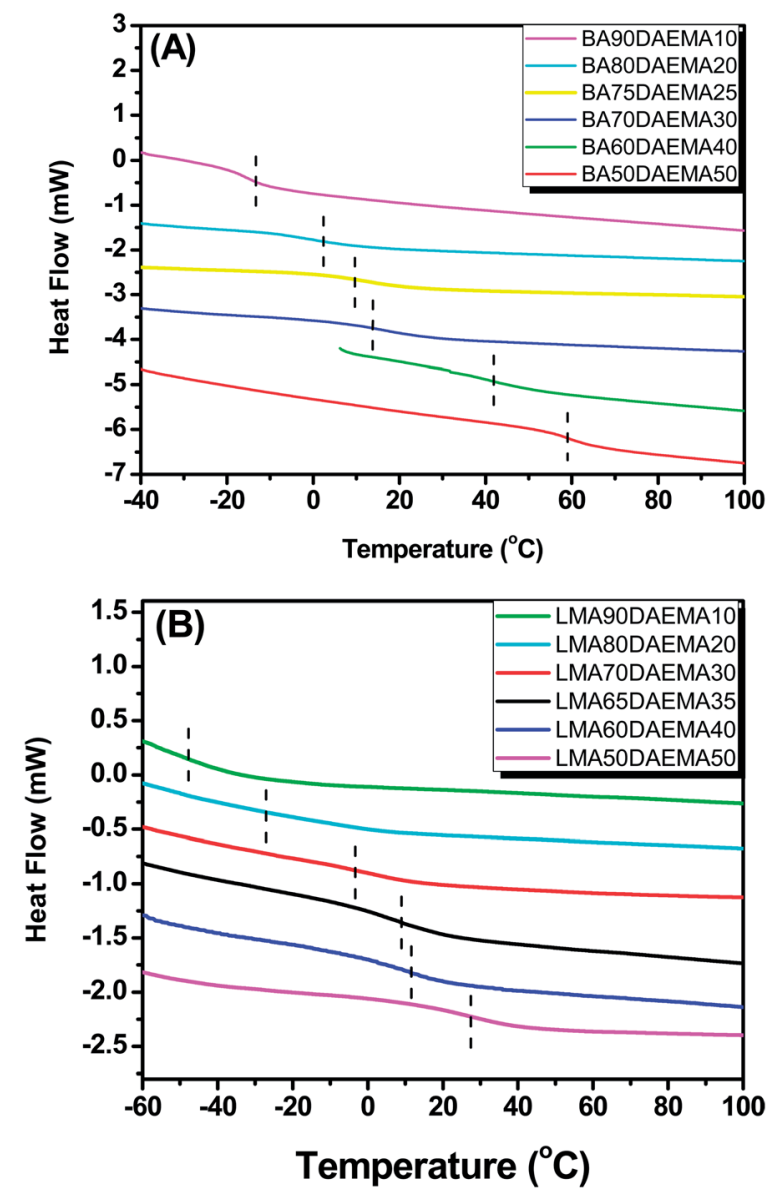

Fig. 4 DSC curves of (A) Cell-g-P(BA-co-DAEMA) and (B) Cell-g$\mathrm{P}(\mathrm{LMA}-\mathrm{CO}-\mathrm{DAEMA})$. In each plot, the DAEMA mole percent values increase for curves ordered from top to bottom.

high DAEMA content makes these materials glassy at room temperature and prone to fracture when handled.

Fig. 6(A) shows tensile stress-strain curves for Cell-g-P(BA-coDAEMA) copolymers with intermediate DAEMA content. All three samples show failure strains greater than $500 \%$. Sample BA80DAEMA20 did not fail, but underwent continuous elongation to a strain of $2500 \%$, with the tensile stress never exceeding 0.5 MPa. Cell-g-P(BA-co-DAEMA) copolymers with 25 and 30\% DAEMA content behaved differently, showing sharp increases in stress at low strain followed by ductile yielding and elasto-plastic deformation up to failure. The yield stresses in these copolymers are greater than $1.5 \mathrm{MPa}$. The $T_{\mathrm{g}}$ values for these samples (Fig. 4(A)) are about $10-20{ }^{\circ} \mathrm{C}$ below ambient temperature. These observations suggest an optimal DAEMA content between 25 and 40 mol\% leads to graft copolymers with a suitable balance between side-chain attraction (imparting elastic character and ability to support tensile stress) and chain disentanglement (enabling large strain deformation and postponing failure to higher strains). These properties can be tuned by varying the DAEMA content.

Fig. 6(B) shows tensile stress-strain results for Cell-g-P(LMAco-DAEMA) graft copolymers. The copolymers with the lowest and highest DAEMA contents $(10-20 \%$ and $50 \%$, respectively) gave films that were too liquid-like or too brittle to form good films for tensile testing. Again, the optimal DAEMA content seems to be in the $25-45 \%$ range, yielding copolymers with $T_{\mathrm{g}}$ values $10-30{ }^{\circ} \mathrm{C}$ below ambient temperature. The three samples with intermediate DAEMA content $(30,35$, and $40 \%)$ all showed steep stress increases at low strain, ductile yielding, and elastoplastic deformation to large failure strains $(>500 \%)$. As DAEMA content increases, the failure strain decreases, but the failure tensile stress increases. The tensile strengths of the Cell-g$\mathrm{P}$ (LMA-co-DAEMA) graft copolymers were generally less than those of the Cell-g-P(BA-co-DAEMA) copolymers. This suggests that the long-chain LMA monomers disrupt the side chain attraction of the DAEMA monomers, thus reducing the ability of the LMA-containing copolymers to sustain tensile stress.

Considering the tensile stress-strain data at small strains (not shown here), none of the graft copolymers show linear elastic behavior above about 1\% strain. Recognizing the limited range of linear elasticity in these materials, we still equate the initial stress-strain slope with the Young's modulus. For Cell- $g$ P(BA-co-DAEMA) copolymers containing 20, 25, and $30 \mathrm{~mol} \%$ DAEMA (Fig. 6(A)), the corresponding Young's modulus values are $8.9,71$, and $99 \mathrm{MPa}$. For Cell-g-P(LMA-co-DAEMA), the Young's modulus values are 20,56, and 58 MPA for copolymers
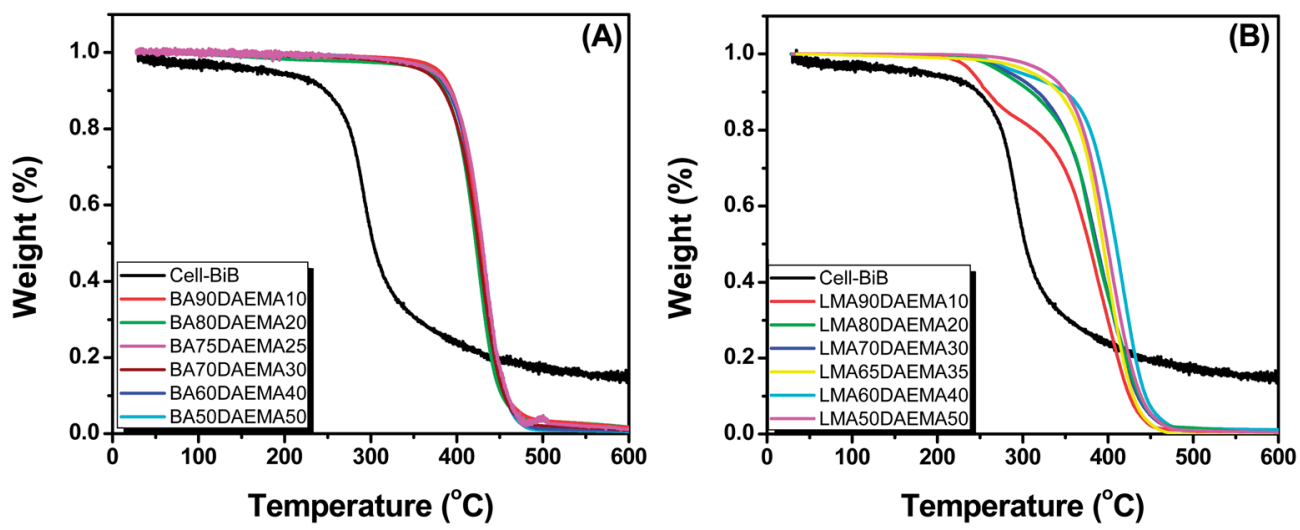

Fig. 5 TGA curves of (A) Cell-g-P(BA-co-DAEMA) and (B) Cell-g-P(LMA-CO-DAEMA) graft copolymers. 

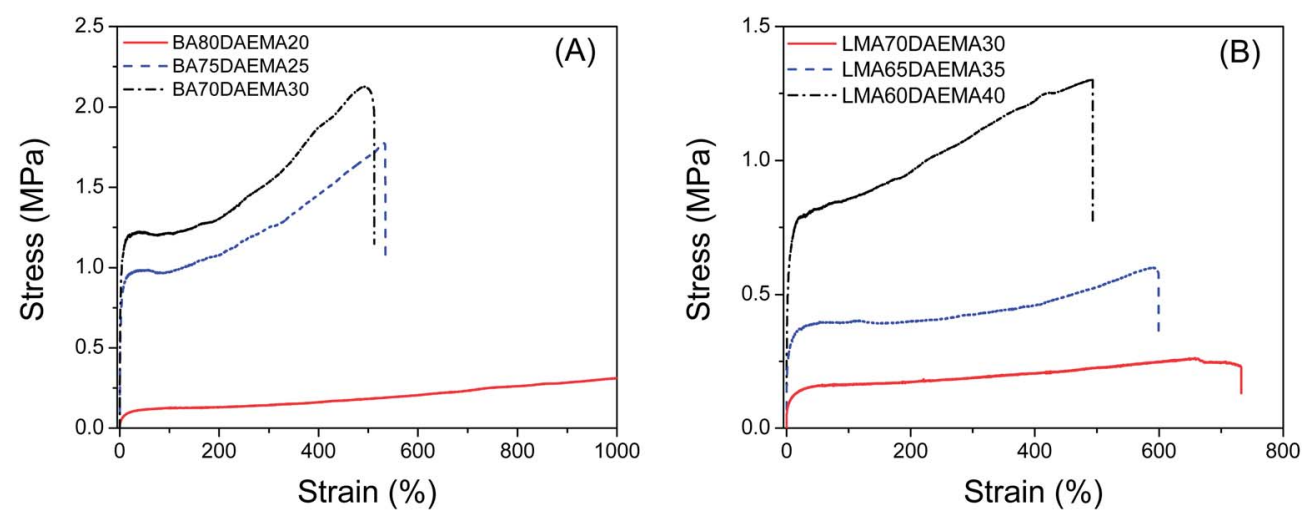

Fig. 6 Stress-strain curves for (A) Cell-g-P(BA-co-DAEMA) and (B) Cell-g-P(LMA-co-DAEMA) graft copolymers with different monomer feed ratios.

with 30, 40, and 45 mol\% DAEMA, respectively. The apparent Young's moduli of these graft copolymers definitely increase with DAEMA content. However, the elastic properties of these cellulose-based graft copolymers differ from those of firstgeneration ABA triblock copolymers, which manifest linear elasticity up to significantly larger strains.

Creep compliance equals the time-dependent strain divided by the constant applied stress. ${ }^{57}$ Fig. 7 shows the results for creep compliance under applied tensile stress (left-hand plots with increasing compliance) as well as creep recovery after stress removal (right-hand plots with decreasing compliance), both plotted as compliance $v s$. time curves. The linearity of the creep compliance data between $t=5$ and 10 min indicates that steady-state creep was attained in all of the samples. The $y$-intercept and slope of the steady state creep compliance $v s$. time yields the elastic compliance $J_{\mathrm{s}}^{0}$, the extensional viscosity $\eta_{0}$, and their product, the relaxation time $\tau$. Upon removal of the tensile stresses, all of the creep recovery curves reached plateau compliance values by the end of the recovery period. The

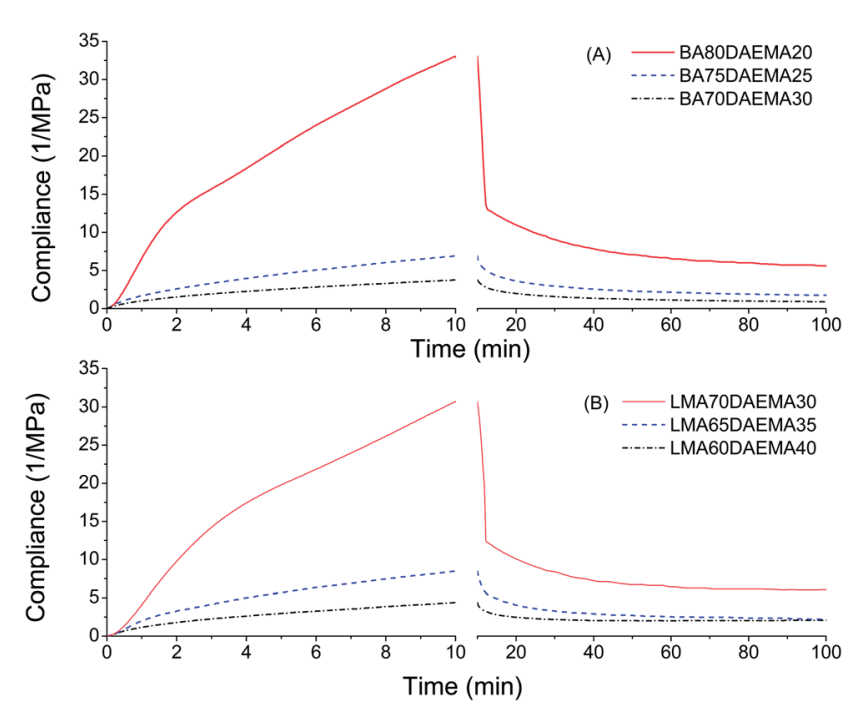

Fig. 7 Creep compliance and recovery curves for (A) Cell-g-P(BA-coDAEMA) and (B) Cell-g-P(LMA-CO-DAEMA) graft copolymers with different monomer feed ratios.
Experimental section describes the computation of the elastic strain recovery from the maximum and plateau residual compliances. The values of $J_{\mathrm{s}}^{0}, \eta_{0}, \tau$, and $\chi$ for all samples are summarized in Table 3.

These results show that for both sets of graft copolymers, $J_{\mathrm{s}}^{0}$ decreases and $\eta_{0}$ increases with increasing DAEMA content. Values of $1 / J_{\mathrm{s}}^{0}$ (units of MPa), representing the materials' elastic character, increase with DAEMA content. Thus as DAEMA molar fraction increases, the copolymer has increasing elastic character as well as higher extensional viscosity, or resistance to creep. Although the relaxation time increases slightly with DAEMA content, the value of $\tau$ is between 4 and $6 \mathrm{~min}$ for all of the copolymers. The magnitude of the relaxation time may be controlled by the dynamics of the long-range deformation of the Cell-BiB main chain during creep, with a secondary effect of increasing side-chain attraction as DAEMA molar content increases.

The samples deformed substantially during the creep testing, with some samples showing tensile strains as large as $65 \%$. Upon removal of the tensile stresses, all of the graft copolymers showed elastic strain recovery values between $50 \%$ and $85 \%$ (see Table 3), indicative of rubber-like elasticity. For Cell- $g$-P(LMA-co-DAEMA) graft copolymers, the elastic recovery clearly increased with LMA content, perhaps due to the increased molecular mobility of the monomer's long alkyl chains. For Cell-g-P(BA-co-DAEMA) graft copolymers, the dependence of $\chi$ on BA content is not clear, but all of these copolymers have relatively high values of elastic recovery.

Overall, the mechanical property results demonstrate that by changing the DAEMA content, the room temperature

Table 3 Copolymer properties obtained from creep recovery tests

\begin{tabular}{llcll}
\hline Sample & $J_{\mathrm{s}}^{0}\left(\mathrm{MPa}^{-1}\right)$ & $\eta_{\mathrm{o}}(\mathrm{MPa} \cdot \mathrm{s})$ & $\tau(\mathrm{min})$ & $\chi(\%)$ \\
\hline BA80DAEMA20 & 9.892 & 25.7 & 4.23 & 83.4 \\
BA75DAEMA25 & 2.201 & 126.3 & 4.63 & 73.9 \\
BA70DAEMA30 & 1.376 & 250.4 & 5.74 & 78.9 \\
LMA70DAEMA30 & 8.621 & 27.2 & 3.90 & 80.5 \\
LMA65DAEMA35 & 2.988 & 108.3 & 5.40 & 71.8 \\
LMA60DAEMA40 & 1.554 & 210.2 & 5.44 & 53.6
\end{tabular}


viscoelastic behavior of these graft copolymers can be changed significantly. Increasing DAEMA content may increase the strength of side-chain attraction, resulting in greater tensile strength, toughness, extensional viscosity, and resistance to creep. All of the graft copolymers undergo elasto-plastic deformation to large strain deformation (500\% or more) before experiencing failure. Creep recovery tests show that all of these graft copolymers have large elastic strain recovery after undergoing large tensile strains.

\section{Hydrophobicity and morphology}

DAEMA monomer has hydrocarbon-based hydrophenanthrene structure, which can increase the hydrophobicity of attached polymers, as demonstrated in prior reports. ${ }^{58}$ Thus Cell- $g$-P(BAco-DAEMA) and Cell-g-P(LMA-co-DAEMA) graft copolymers with DAEMA units in the side chains are expected to be more hydrophobic than the starting Cell-BiB macroinitiator. Contact angle measurements were employed to characterize the hydrophobicity of cellulose-based graft copolymers and the Cell-BiB macroinitiator. The polymers in THF solution were spin-cast on glass substrates to give polymer thin films for contact angle measurement. Five different spots on each film sample were tested and an average contact angle was obtained. Fig. 8(A) shows the contact angle values of water drops on graft copolymer films versus the DAEMA molar content. Fig. 8(B) shows images of water droplet on the films of Cell-BiB, Cell- $g$-P(BA-coDAEMA) and Cell- $g$-P(LMA-co-DAEMA). Compared with Cell-BiB macroinitiator (contact angle: $\sim 77^{\circ}$ ), both Cell- $g$-P(BA-coDAEMA) and Cell- $g$-P(LMA-co-DAEMA) graft copolymers have higher contact angles, ranging from $89^{\circ}$ to $105^{\circ}$, indicating that DAEMA increases the hydrophobicity of the graft copolymers. The DAEMA content in the graft copolymers appears to have little effect on the contact angle. A possible reason may be that the hydrophobic hydrophenanthrene moieties prefer to stay on the surface of films, a result seen in earlier studies of ligninrosin composites. ${ }^{59}$

Atomic force microscopy (AFM) was employed to image the surface morphologies of Cell- $g$-P(BA-co-DAEMA) and Cell- $g$ $\mathrm{P}$ (LMA-co-DAEMA) copolymers. As shown in Fig. 9, the phase images of both Cell- $g$-P(BA-co-DAEMA) and Cell- $g$-P(LMA-coDAEMA) copolymers exhibited homogeneous morphologies with no observed microphase separation. There are two possible scenarios here. First, the graft copolymers may be a truly homogeneous system. Second, given the rigidity of cellulose and PDAEMA chains, if phase-separated, may be embedded in a rubbery matrix of PBA or PLMA, with only the homogeneous matrix observed on the surface. The bulk morphologies were characterized by small-angle X-ray scattering (SAXS). Cell- $g$ P(BA-co-DAEMA) copolymers show a broad, weak correlation peak (Fig. 9(C)), indicating that only disordered domains are formed in these copolymers. In contrast, no scattering peaks
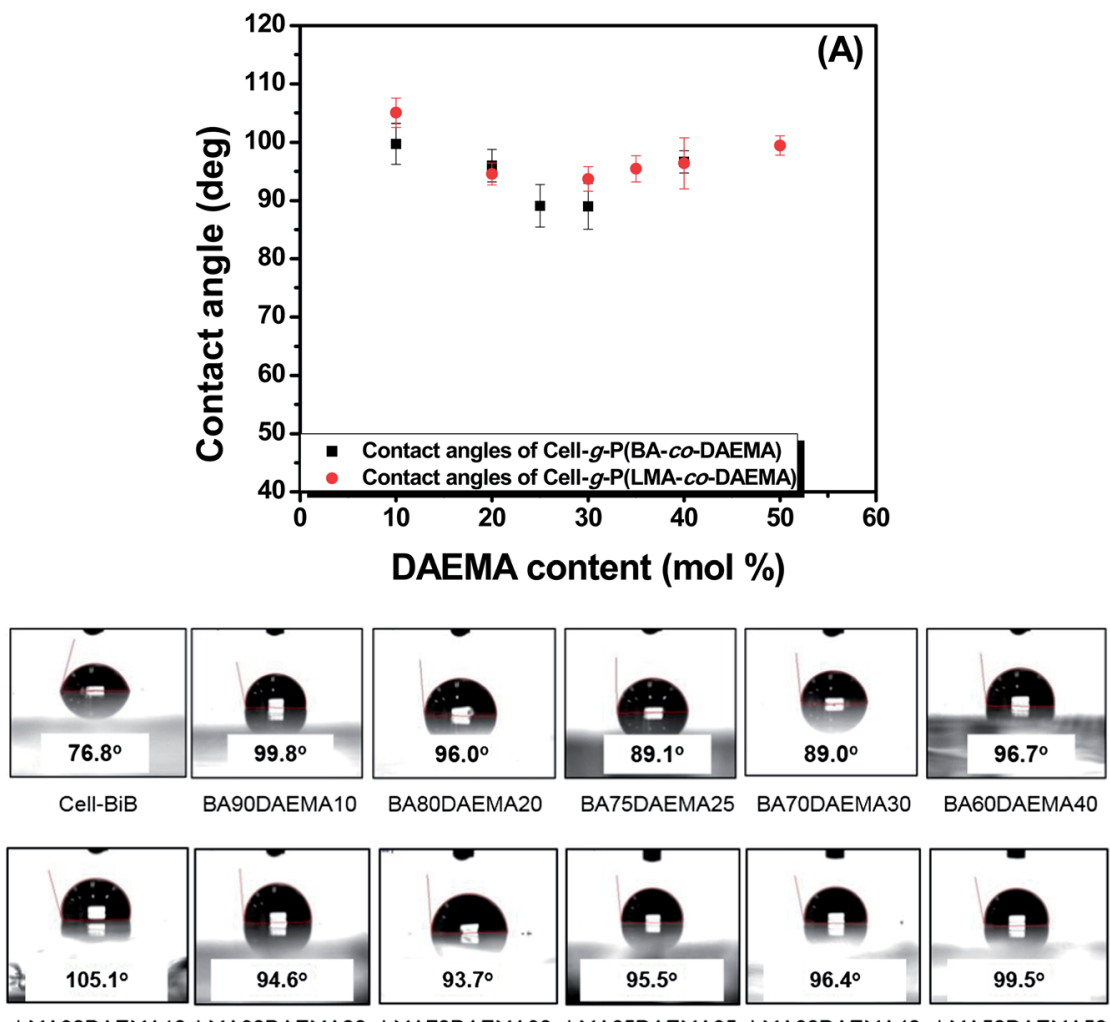

LMA90DAEMA10 LMA80DAEMA20 LMA70DAEMA30 LMA65DAEMA35 LMA60DAEMA40 LMA50DAEMA50

(B)

Fig. 8 (A) Plot of contact angles of Cell-g-P(BA-co-DAEMA) and Cell-g-P(LMA-CO-DAEMA) against DAEMA content. (B) Images of water droplets on the films of Cell-BiB, Cell-g-P(BA-CO-DAEMA) and Cell-g-P(LMA-CO-DAEMA). 

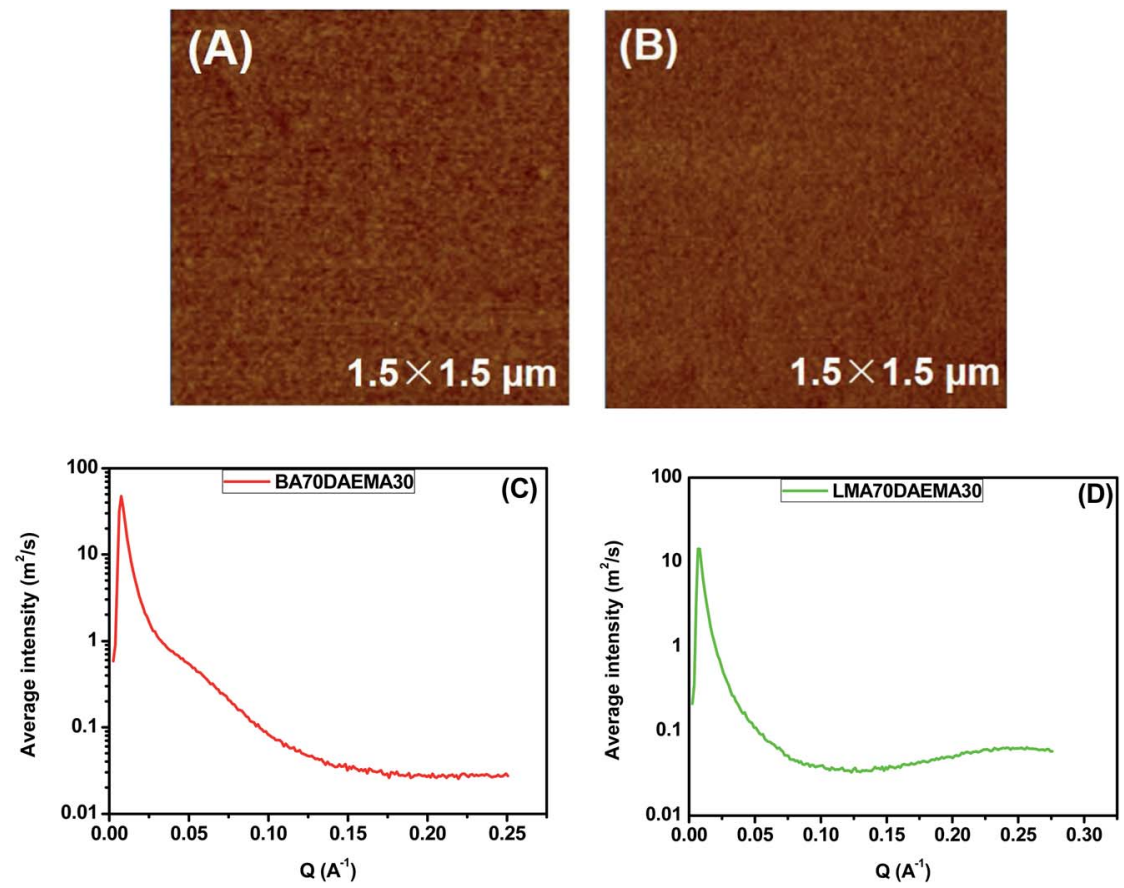

Fig. 9 (A) AFM phase image of Cell-g-P(BA-Co-DAEMA) film annealed at $150{ }^{\circ} \mathrm{C}$ (sample: BA80DAEMA20); (B) AFM phase image of Cell-gP(LMA-CO-DAEMA) film annealed at $150^{\circ} \mathrm{C}$ (sample: LMA70DAEMA30); (C) SAXS profile for Cell-g-P(BA-co-DAEMA) (BA70DAEMA30); (D) SAXS profile for Cell-g-P(LMA-CO-DAEMA) (LMA70DAEMA30).

were observed for Cell-g-P(LMA-co-DAEMA) copolymers, suggesting the formation of mostly homogenous structures. Coupled with AFM surface morphologies, our polymers exhibit similar structures to those grafted copolymers with BA and MMA as side chains reported earlier. ${ }^{38}$

In the classic TPE triblock copolymer system, the soft polymer chains should form a matrix with the rigid segments dispersed as well-ordered minority domains. ${ }^{32,60,61}$ However in our case, the rigid cellulose backbone is less than $1 \mathrm{wt} \%$ of the entire graft copolymer. The soft PBA or PLMA segment is a majority component with another rigid PDAEMA as a minority component. This particular system could be very similar to our early report on the Cell- $g$-P(BA-co-MMA) ${ }^{38}$ The mechanical properties are largely dictated by the DAEMA content in the graft copolymers. Physical cross-links are mostly likely originated from both DAEMA and cellulose, which could form separated glassy domains of DAEMA and aggregated cellulose domains. When the sample is stretched, the initial deformation is attributed to soft BA or LMA chain in the side chains. When the stretching increases, the physical cross-linked DAEMA and cellulose chains start to take the higher stress transmitted from soft matrix. Particularly in the graft architecture, the cellulose chains are stretched for taking higher stress.

\section{Conclusions}

In conclusion, we prepared two graft copolymers Cell- $g$-P(BA-coDAEMA) and Cell- $g$-P(LMA-co-DAEMA) with cellulose as backbone and rosin derivative as side chains via "grafting from" ATRP. By adjusting the DAEMA content, high molecular weight graft copolymers with various $T_{\mathrm{g}}$ were obtained. These graft copolymers exhibited good elastomeric properties, excellent hydrophobicity, and good thermal stability, which were confirmed by mechanical property tests, contact angle measurements, and TGA, respectively. Given the fact that cellulose, DAEMA, and LMA are all sourced from renewable natural resources, we anticipate that these renewable polymeric materials with graft copolymer architecture may be attractive as potential candidates for use as next-generation thermoplastic elastomer materials. These materials may be able to replace TPEs in some applications which can tolerate some amount of creep, as long as the elastic properties and tensile strength at large deformation can be further improved.

\section{Experimental section}

\section{Materials}

$n$-Butyl acrylate (BA), lauryl methacrylate (LMA), $N, N$-dimethylformamide (DMF), tetrahydrofuran (THF), toluene, methanol, $\mathrm{Cu}(\mathrm{I}) \mathrm{Br}$, and $N, N, N^{\prime}, N^{\prime}, N^{\prime \prime}$-pentamethyldiethylenetriamine (PMDETA) were purchased from Sigma-Aldrich. Dehydroabietic ethyl methacrylate (DAEMA) and cellulose 2-bromoisobutyrylate (Cell-BiB) were synthesized according to procedures reported in early work. ${ }^{38,51}$ BA and LMA were passed through a basic alumina column before polymerization. Toluene were refluxed with sodium and distilled under a nitrogen atmosphere before use. All other reagents were used as received.

\section{Characterization}

${ }^{1} \mathrm{H}(400 \mathrm{MHz})$ NMR spectra were recorded on a Varian Mercury spectrometer with tetramethylsilane (TMS) as an internal 
reference. Gel Permeation Chromatography (GPC) was performed using a Waters system equipped with a 515 HPLC pump, a 2410 refractive index detector, and three Styragel columns (HR1, HR3, HR4 in the effective molecular weight range of 100-5000, 50030000 , and 5000-500 000, respectively) with HPLC grade THF as the eluent at $30{ }^{\circ} \mathrm{C}$ and a flow rate of $1.0 \mathrm{~mL} \mathrm{~min}{ }^{-1}$. THF and polymer solutions were filtered over microfilters with a pore size of $0.2 \mu \mathrm{m}$ (Nylon, Millex-HN $13 \mathrm{~mm}$ Syringes Filters, Millipore, USA). The columns were calibrated against polystyrene standards. Differential scanning calorimetry (DSC) experiments were conducted on a DSC Q2000 instrument (TA instruments). The samples were heated from $-70{ }^{\circ} \mathrm{C}$ to $200{ }^{\circ} \mathrm{C}$ at a rate of $10{ }^{\circ} \mathrm{C}$ $\min ^{-1}$, maintained at $200^{\circ} \mathrm{C}$ for $2 \mathrm{~min}$ and then cooled to $-70^{\circ} \mathrm{C}$ at a rate of $10^{\circ} \mathrm{C} \mathrm{min}^{-1}$. The data were collected from the second heating scan. The average sample mass was about $5 \mathrm{mg}$, and the

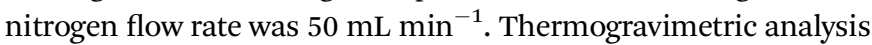
(TGA) was operated on a Q5000 TGA system (TA instruments), ramping from $25{ }^{\circ} \mathrm{C}$ to $1000{ }^{\circ} \mathrm{C}$ at a rate of $10{ }^{\circ} \mathrm{C} \mathrm{min}{ }^{-1}$, and maintaining at $1000^{\circ} \mathrm{C}$ for $5 \mathrm{~min}$ under nitrogen gas at a flow rate of $20 \mathrm{~mL} \mathrm{~min}{ }^{-1}$. Contact angle test data were collected on a VCAOptima goniometer (AST Products, Inc). Taping mode atomic force microscopy (AFM) experiments were conducted using a Multimode Nanoscope V system (Veeco, Santa Barbara, CA). The measurements were performed using $\mathrm{Si}$ cantilevers with a nominal spring constant and resonance frequency at 20-80 N $\mathrm{m}^{-1}$ and $230-410 \mathrm{kHz}$, respectively (TESP, Bruker AFM probes, Santa Barbara, CA). The height and phase images were acquired simultaneously at the set-point ratio $A / A_{0}=0.9-0.95$, where $A$ and $A_{0}$ means the "tapping" and "free" cantilever amplitudes, respectively. The polymer thin films were prepared by spincoating in DMF and thermally annealed at $150{ }^{\circ} \mathrm{C}$ under vacuum for $48 \mathrm{~h}$. Small-angle X-ray scattering (SAXS) experiments were conducted on the Rigaku SMAX-3000 configured with MicroMax007 rotating anode micro focus X-ray source, three-pinhole camera, two sample chambers and multi-wire 2D proportional counter (MWPC). The sample-detector distance is about $1500 \mathrm{~mm}$.

Tensile stress-strain testing was performed in an Instron 5543A testing machine. The film samples were prepared by casting THF solutions of polymers on polytetrafluoroethylene substrate followed by removal of solvent at room temperature for $48 \mathrm{~h}$. The films were further dried at $40{ }^{\circ} \mathrm{C}$ under vacuum to constant weight. Dumbbell samples with a length of $17.9 \mathrm{~mm}$ and width of $4.7 \mathrm{~mm}$ were cut from the cast films and tested at room temperature with the crosshead speed of $25 \mathrm{~mm} \mathrm{~min}^{-1}$.

Tensile creep and creep recovery experiments were performed using a dynamic mechanical analyzer (TA Instruments RSAIII). The test specimens were prepared in the shape of rectangular film strips, typically $\sim 6 \mathrm{~mm}$ wide and over $25 \mathrm{~mm}$ long. Their thickness varied from sample to sample, ranging between $0.3 \mathrm{~mm}$ and $1.2 \mathrm{~mm}$, and the gauge length for the testing was $15 \mathrm{~mm}$. In a tensile creep and recovery test, a film specimen is subjected to a constant stress level of $0.02 \mathrm{MPa}$ for 10 minutes, and the strain in response to the stress was recorded during this period. After 10 minutes, the tensile stress was released, and the strain recovery was recorded for at least another 100 minutes.
From the tensile creep and creep recovery experiments, several properties of interest can be obtained, namely the elastic creep compliance $J_{\mathrm{s}}^{0}$, the extensional viscosity $\eta_{0}$, the relaxation time $\tau$, and the percentage of elastic strain recovery $\chi$. To obtain these properties, first a strain-time curve is converted into a compliance-time curve by normalizing the strain $\varepsilon$ with the constantly applied stress level $\sigma_{0}$. Then the steady-state part of the compliance curve is fitted with a linear function of time. The $y$-intercept of fitted line gives $J_{\mathrm{s}}^{0}$, while the inverse of the slope gives $\eta_{0}$. The relaxation time $\tau$ is calculated as the product of $J_{\mathrm{s}}^{0}$ and $\eta_{0}$, to the first order of approximation. The recoverable compliance, $J_{\mathrm{r}}$, is the difference between the maximum compliance $\left(J_{\max }\right)$ measured when the stress is removed, and the plateau (residual) compliance value $\left(J_{\mathrm{nr}}\right)$ measured at the end of the test. The percentage of elastic strain recovery is calculated as

$$
\chi=\left[\left(J_{\max }-J_{\mathrm{nr}}\right) / J_{\max }\right] \times 100 \%
$$

\section{Cellulose- $g$-poly $(n$-butyl acrylate-co-dehydroabietic ethyl methacrylate) (Cell-g-P(BA-co-DAEMA))}

Take sample BA80DAEMA20 as an example, a mixture of Cell$\mathrm{BiB}(3.2 \mathrm{mg}, 0.01 \mathrm{mmol}$ of $\mathrm{Br}), \mathrm{Cu}(\mathrm{I}) \mathrm{Br}(1.4 \mathrm{mg}, 0.01 \mathrm{mmol})$, and dry toluene $(1 \mathrm{~mL})$ was introduced into a Schlenk flask and purged with nitrogen for $15 \mathrm{~min}$. BA (1.03 $\mathrm{g}, 8 \mathrm{mmol})$, DAEMA (0.83 g, $2 \mathrm{mmol})$, and PMDETA ( $1.8 \mathrm{mg}, 0.01 \mathrm{mmol}$ ) were dissolved in $2 \mathrm{~mL}$ dry toluene in a round bottom flask and purged with nitrogen for $15 \mathrm{~min}$. Then the solution of monomers and PMDETA ligand were transferred to the Schlenk flask under nitrogen atmosphere by syringe. The reaction flask was placed into an oil bath preheated at $80{ }^{\circ} \mathrm{C}$ for 24 hours under continuous stirring. The polymerization was stopped by diluting the reaction mixture with THF. The products were passed through a neutral alumina column and precipitated in cold methanol three times and dried to constant weight (yield: $80 \%$ ). ${ }^{1} \mathrm{H}$ NMR $\left(\mathrm{CDCl}_{3}, \delta\right)$ : 6.7-7.2 (m, aromatic protons); 3.7-4.4 (m, $\mathrm{OCH}_{2-}$ $\mathrm{CH}_{2} \mathrm{O}$ in PDAEMA and $\mathrm{OCH}_{2}$ in PBA); $2.6-2.8$ (protons next to aromatic ring).

\section{Cellulose- $g$-poly(lauryl methacrylate-co-dehydroabietic ethyl methacrylate) (Cell-g-P(LMA-co-DAEMA))}

Cell-g-P(LMA-co-DAEMA) was polymerized in a similar procedure to the synthesis of Cell-g-P(BA-co-DAEMA). The polymerization temperature was set at $90{ }^{\circ} \mathrm{C}$. Take sample LMA70DAEMA30 as an example, Cell-BiB (3.2 $\mathrm{mg}, 0.01 \mathrm{mmol}$ of $\mathrm{Br}), \mathrm{Cu}(\mathrm{I}) \mathrm{Br}(1.4 \mathrm{mg}, 0.01 \mathrm{mmol})$ were dissolved in dry toluene $(1 \mathrm{~mL})$ in a Schlenk flask and purged with nitrogen for $15 \mathrm{~min}$. LMA (1.78 g, $7 \mathrm{mmol})$, DAEMA ( $1.24 \mathrm{~g}, 3 \mathrm{mmol})$, and PMDETA $(1.8 \mathrm{mg}, 0.01 \mathrm{mmol})$ were dissolved in a small rounded bottom flask by $2 \mathrm{~mL}$ of dry toluene and purged with nitrogen for 15 min. Then the solution of monomers and PMDETA ligand were added into the Schlenk flask under nitrogen atmosphere by syringe. After polymerization, the reaction mixture was also diluted with THF, passed through an alumina column and precipitated in cold methanol three times. The final product was dried under vacuum to constant weight (yield: $70 \%$ ). 
${ }^{1} \mathrm{H}$ NMR $\left(\mathrm{CDCl}_{3}, \delta\right): 6.7-7.2$ (m, aromatic protons); 3.7-4.3 (m, $\mathrm{OCH}_{2} \mathrm{CH}_{2} \mathrm{O}$ in PDAEMA and $\mathrm{OCH}_{2}$ in PLMA); 2.6-2.8 (protons next to aromatic ring).

\section{Acknowledgements}

We would like to acknowledge support from the China International Science and Technology Cooperation program (2011DFA32440), the National Natural Science Foundation of China (31200447), the U.S. National Science Foundation (Career Award: DMR-1252611) and the USDA NIFA program under Award 2011-51160-31205. We are grateful for Materials Analysis Group of Rigaku Americas Corporation to carry out the SAXS experiments.

\section{References}

1 G. W. Coates and M. A. Hillmyer, Macromolecules, 2009, 42, 7987-7989.

2 M. Okada, Prog. Polym. Sci., 2002, 27, 87-133.

3 A. J. Ragauskas, C. K. Williams, B. H. Davison, G. Britovsek, J. Cairney, C. A. Eckert, W. J. Frederick, J. P. Hallett, D. J. Leak, C. L. Liotta, J. R. Mielenz, R. Murphy, R. Templer and T. Tschaplinski, Science, 2006, 311, 484-489. 4 R. T. Mathers, J. Polym. Sci., Part A: Polym. Chem., 2012, 50,115.

5 S. A. Miller, ACS Macro Lett., 2013, 2, 550-554.

6 K. Yao and C. Tang, Macromolecules, 2013, 46, 1689-1712.

7 P. Wilbon, F. Chu and C. Tang, Macromol. Rapid Commun., 2013, 34, 8-37.

8 A. Corma, S. Iborra and A. Velty, Chem. Rev., 2007, 107, 24112502.

9 D. R. Dodds and R. A. Gross, Science, 2007, 318, 1250-1251.

10 C. K. Williams and M. A. Hillmyer, Polym. Rev., 2008, 48, 110.

11 A. Gandini, Macromolecules, 2008, 41, 9491-9504.

12 S. Mecking, Angew. Chem., Int. Ed., 2004, 43, 1078-1085.

13 M. A. R. Meier, J. O. Metzger and U. S. Schubert, Chem. Soc. Rev., 2007, 36, 1788-1802.

14 F. Seniha Güner, Y. YagcI and A. Tuncer Erciyes, Prog. Polym. Sci., 2006, 31, 633-670.

15 A. K. Bhowmick and H. Stephens, Handbook of Elastomers, Taylor \& Francis, 2nd edn, 2000.

16 P. R. Lewis and C. Price, Polymer, 1972, 13, 20-26.

17 D. McIntyre and E. Campos-Lopez, Macromolecules, 1970, 3, 322-327.

18 E. Campos-Lopez, D. McIntyre and L. J. Fetters, Macromolecules, 1973, 6, 415-423.

19 A. Nese, J. Mosnáček, A. Juhari, J. A. Yoon, K. Koynov, T. Kowalewski and K. Matyjaszewski, Macromolecules, 2010, 43, 1227-1235.

20 J. D. Tong, G. Moineau, P. Leclère, J. L. Brédas, R. Lazzaroni and R. Jérôme, Macromolecules, 1999, 33, 470-479.

21 K. Matyjaszewski and J. Xia, Chem. Rev., 2001, 101, 29212990.

22 N. V. Tsarevsky and K. Matyjaszewski, Chem. Rev., 2007, 107, 2270-2299.
23 K. Matyjaszewski, Macromolecules, 2012, 45, 4015-4039.

24 K. Matyjaszewski and N. V. Tsarevsky, Nat. Chem., 2009, 1, 276-288.

25 B. Dufour, C. Tang, K. Koynov, Y. Zhang, T. Pakula and K. Matyjaszewski, Macromolecules, 2008, 41, 2451-2458.

26 J. Mosnáček and K. Matyjaszewski, Macromolecules, 2008, 41, 5509-5511.

27 J. Mosnáček, J. A. Yoon, A. Juhari, K. Koynov and K. Matyjaszewski, Polymer, 2009, 50, 2087-2094.

28 A. Juhari, J. Mosnáček, J. A. Yoon, A. Nese, K. Koynov, T. Kowalewski and K. Matyjaszewski, Polymer, 2010, 51, 4806-4813.

29 E. M. Frick, A. S. Zalusky and M. A. Hillmyer, Biomacromolecules, 2003, 4, 216-223.

30 J. Shin, M. T. Martello, M. Shrestha, J. E. Wissinger, W. B. Tolman and M. A. Hillmyer, Macromolecules, 2010, 44, 87-94.

31 C. L. Wanamaker, L. E. O'Leary, N. A. Lynd, M. A. Hillmyer and W. B. Tolman, Biomacromolecules, 2007, 8, 36343640.

32 C. L. Wanamaker, M. J. Bluemle, L. M. Pitet, L. E. O'Leary, W. B. Tolman and M. A. Hillmyer, Biomacromolecules, 2009, 10, 2904-2911.

33 H. Iatrou, J. W. Mays and N. Hadjichristidis, Macromolecules, 1998, 31, 6697-6701.

34 Y. Zhu, E. Burgaz, S. P. Gido, U. Staudinger, R. Weidisch, D. Uhrig and J. W. Mays, Macromolecules, 2006, 39, 44284436.

35 Y. Duan, M. Thunga, R. Schlegel, K. Schneider, E. Rettler, R. Weidisch, H. W. Siesler, M. Stamm, J. W. Mays and N. Hadjichristidis, Macromolecules, 2009, 42, 41554164.

36 R. Weidisch, S. P. Gido, D. Uhrig, H. Iatrou, J. Mays and N. Hadjichristidis, Macromolecules, 2001, 34, 6333-6337.

37 Y. Schneider, N. A. Lynd, E. J. Kramer and G. C. Bazan, Macromolecules, 2009, 42, 8763-8768.

38 F. Jiang, Z. Wang, Y. Qiao, Z. Wang and C. Tang, Macromolecules, 2013, 46, 4772-4780.

39 S. Kobayashi, K. Kashiwa, J. Shimada, T. Kawasaki and S.-i. Shoda, Makromol. Chem., Macromol. Symp., 1992, 5455, 509-518.

40 T. E. Wagner, H. G. Chai and A. S. Warfield, J. Am. Chem. Soc., 1969, 91, 2388-2389.

41 V. Favier, H. Chanzy and J. Y. Cavaille, Macromolecules, 1995, 28, 6365-6367.

42 S. Maiti, S. S. Ray and A. K. Kundu, Prog. Polym. Sci., 1989, 14, 297-338.

43 A. M. Atta, I. F. Nassar and H. M. Bedawy, React. Funct. Polym., 2007, 67, 617-626.

44 I. Bicu and F. Mustata, J. Polym. Sci., Part A: Polym. Chem., 2005, 43, 6308-6322.

45 J. Wang, J. Yu, Y. Liu, Y. Chen, C. Wang, C. Tang and F. Chu, Green Mater., 2013, 1, 105-113.

46 P. Wilbon, A. L. Gulledge, B. C. Benicewicz and C. Tang, Green Mater., 2013, 1, 96-104.

47 Y. Chen, P. A. Wilbon, J. Zhou, M. Nagarkatti, C. Wang, F. Chu and C. Tang, Chem. Commun., 2013, 49, 297-299. 
48 Y. Chen, P. A. Wilbon, Y. P. Chen, J. Zhou, M. Nagarkatti, C. Wang, F. Chu, A. W. Decho and C. Tang, RSC Adv., 2012, 2, 10275-10282.

49 J. Wang, Y. P. Chen, K. Yao, P. A. Wilbon, W. Zhang, L. Ren, J. Zhou, M. Nagarkatti, C. Wang, F. Chu, X. He, A. W. Decho and C. Tang, Chem. Commun., 2012, 48, 916-918.

50 J. Yu, Y. Liu, X. Liu, C. Wang, J. Wang, F. Chu and C. Tang, Green Chem., 2014, DOI: 10.1039/C3GC41550C.

51 Y. Zheng, K. Yao, J. Lee, D. Chandler, J. Wang, C. Wang, F. Chu and C. Tang, Macromolecules, 2010, 43, 5922-5924.

52 P. A. Wilbon, Y. Zheng, K. Yao and C. Tang, Macromolecules, 2010, 43, 8747-8754.

53 J. Wang, K. Yao, C. Wang, C. Tang and X. Jiang, J. Mater. Chem. B, 2013, 1, 2324-2332.

54 G. Çayli and M. A. R. Meier, Eur. J. Lipid Sci. Technol., 2008, 110, 853-859.
55 F. Dutertre, P.-Y. Pennarun, O. Colombani and E. Nicol, Eur. Polym. J., 2011, 47, 343-351.

56 T. Meng, X. Gao, J. Zhang, J. Yuan, Y. Zhang and J. He, Polymer, 2009, 50, 447-454.

57 J. D. Ferry, Viscoelastic Properties of Polymers, John Wiley \& Sons, New York, 1980, pp. 35-129.

58 K. Yao, J. Wang, W. Zhang, J. S. Lee, C. Wang, F. Chu, X. He and C. Tang, Biomacromolecules, 2011, 12, 21712177.

59 J. Wang, K. Yao, A. L. Korich, S. Li, S. Ma, H. J. Ploehn, P. M. Iovine, C. Wang, F. Chu and C. Tang, J. Polym. Sci., Part A: Polym. Chem., 2011, 49, 3728-3738.

60 J. Shin, Y. Lee, W. B. Tolman and M. A. Hillmyer, Biomacromolecules, 2012, 13, 3833-3840.

61 S. Wang, S. V. Kesava, E. D. Gomez and M. L. Robertson, Macromolecules, 2013, 46, 7202-7212. 